\title{
Factors Influencing Small-Scale Fishers' Individual Perceived Wellbeing Satisfaction in Southern Benin
}

\author{
Sètondji Ben-Vital Kolawolé Kpanou ${ }^{1,2}, * \mathbb{C}$, Houinsou Dedehouanou ${ }^{1}$, Sylvain Kpenavoun Chogou ${ }^{3}{ }^{(D)}$, \\ Augustin K. N. Aoudji ${ }^{2}$ and Thomas Dogot ${ }^{2}$ \\ 1 Laboratoire d'Economie Rurale et de Gestion des Exploitations Agricoles, Faculté des Sciences Agronomiques, \\ Université d'Abomey-Calavi, Abomey-Calavi, Cotonou 01 BP 526, Benin; hdedehouanou@hotmail.com \\ 2 Laboratoire d'Economie et de développement Rural, Gembloux Agro-Bio Tech, Université de Liège, \\ 5030 Gembloux, Belgium; augustin.aoudji@gmail.com (A.K.N.A.); thomas.dogot@uliege.be (T.D.) \\ 3 Laboratoire d'Etude sur la Pauvreté et la Performance de l'Agriculture, Faculté des Sciences Agronomiques, \\ Université d'Abomey-Calavi, Abomey-Calavi, Cotonou 01 BP 526, Benin; sylvain.kpenavoun@gmail.com \\ * Correspondence: vital.kpanou@gmail.com; Tel.: +229-97-91-75-57
}

check for

updates

Citation: Kpanou, S.B.-V.K.; Dedehouanou, H.; Chogou, S.K.; Aoudji, A.K.N.; Dogot, T. Factors Influencing Small-Scale Fishers' Individual Perceived Wellbeing Satisfaction in Southern Benin. Sustainability 2021, 13, 6279. https://doi.org/10.3390/su13116279

Academic Editor: Giuseppe

Antonio Di Vita

Received: 31 March 2021

Accepted: 14 May 2021

Published: 2 June 2021

Publisher's Note: MDPI stays neutral with regard to jurisdictional claims in published maps and institutional affiliations.

Copyright: (c) 2021 by the authors. Licensee MDPI, Basel, Switzerland. This article is an open access article distributed under the terms and conditions of the Creative Commons Attribution (CC BY) license (https:// creativecommons.org/licenses/by/ $4.0 /)$.

\begin{abstract}
In southern Benin, the rapid growth of demographics and the need for fishery products have forced public managers to adopt various management measures in the face of anti-ecological methods used by fishers; however, these strategies are often formulated independent from the context. These measures have not remained without consequence on the daily lives of fishers. This paper examines factors influencing fishers' individual perceived wellbeing satisfaction using the social-ecological system framework. Data on 205 small-scale fishers' demographic information, perception of job, and individual wellbeing satisfaction and governance subsystems were collected and analysed by the use of an ordered logistic regression. The results demonstrate that job satisfaction and ownership of water bodies (in contradiction to Ostrom's advocation for commons management) affected fishers' individual perceived wellbeing satisfaction. Fishers likely value ownerships, affecting their perceived wellbeing mainly in the South East. The prohibition of certain fishing gear decreases fishers' individual perceived wellbeing, indicating their attachment to these. Therefore, the question remains as to whether or not the scenarios of eco-sustainability of artisanal fisheries can be managed in the same manner as those related urban dwellers and the public sector. This is in particular reference to the line between urban land property rights, urban dwellers and the state, and property rights on water bodies, fishers, and the state.
\end{abstract}

Keywords: fishers; individual perceived wellbeing; prohibited gears; property rights; southern Benin

\section{Introduction}

Worldwide official estimations indicate that fisheries employed two-thirds of the 59.6 million people included in the primary capture fisheries and aquaculture sectors in 2016 [1]. Fisheries are an important part of the world food system. Fisheries support the livelihoods and food security of more than half a billion people [2]. Globally, artisanal fisheries, which depend on fish stocks such as many natural resources [3], are diversified with a strong anchorage in the family economy [4]. However, the overexploitation of aquatic resources has been the cause of negative impacts on biodiversity, ecosystem services, and livelihoods, especially for poor and vulnerable groups [5]. This situation affects food security and limits poverty alleviation of households that are fishery-dependent [6].

In Benin, inland fishing exclusively remains an artisanal activity and is currently without access barriers. This activity is concentrated in the southern part of the country: the lower reaches of main rivers and lagoon complexes, ancient lakes, and other small lakes [7]. It generates about 600,000 jobs, provides nearly $30 \%$ of the total amount of the consumed animal protein [8], and has represented a major source of income for vulnerable fishing communities throughout generations. The historical settlement around water bodies 
in the study area of indigenous communities (Pedah, Pla, Goun, and Aïzo) since the 15th century has given rise to the governance by traditional standards of the property rights of fisheries [9-12]. Traditional property rights are therefore transferred from one generation to the next and ownership of Acadja (Acadja looks like a fishing pond and is built by placing wooden branches in the lake and fencing them with fishing nets) is considered a right by the owners [11]. As result, there is a density of 117 fishers per $\mathrm{km}^{2}$ which is ten times higher compared to standard in such environments [13]. This density, most likely causes the overexploitation of aquatic resources, which could be linked to the low implementation of a sustainable fisheries management and development policy [14]. Consequences of the high density lead to the reduction of growth time of fish species $[15,16]$.

However, Law $\mathrm{N}^{\circ}$ 2014-2019 of 7 August 2014, regulating fishing and aquaculture in the Benin Republic, provides that water bodies and their resources are part of State property. The two regulatory frameworks thus become contradictory and fishers' property rights are revoked; nets and sedentary fishing gears (Acadja, Mêdokpokonou (Mêdokpokonou is a fixed fishing installation consisting of fine-mesh nets which are set so that even small fish are trapped)), the methods most used by fishers, are therefore prohibited. This disrupts the perception and the conditions of use of the water body by the fishers. Despite water resources' depletion and the shortcoming of alternatives for fishers [17], they remain highly dependent on fish stocks. Therefore, there is a pressure for the development of more fishing technologies which subsequently impacts upon resource availability [18].

Moreover, it is possible that changes in management strategies could have an impact on the job satisfaction of small-scale fishers and their families and communities [19]. It is important to note that job satisfaction plays a key role in human perceived wellbeing; therefore, special consideration should be given to social groups that may gain or lose from any management decisions. A primary concern is to evaluate how the wellbeing of the fishing system's principal actors will be impacted by such management changes [20]. Along the same lines, the level of attachment of fishers to their job can influence the success or failure of fishing management strategies [21,22] Loss and degradation of ecosystem function have complex consequences for the socioecological system as a whole, impairing the flow of ecosystem services upon which humans rely for their livelihoods and wellbeing [23].

While several studies have significantly addressed the issue of job satisfaction and fishers' individual perceived wellbeing satisfaction in developed countries [21,24-28] none of them have thus far comprehensively adopted the social-ecological system framework (SESF). The current study attempts to understand the types of influence exerted by various factors (natural, socio-cultural, economic, and management changes) on fishers' individual perceived wellbeing in order to facilitate a fishery sustainable management process in estuarine and lagoon environments of southern Benin.

\section{Methodology}

2.1. Defining Perceived Wellbeing as an Outcome in Social-Ecological System Framework (SESF)

A global challenge faced by humanity is how to achieve the sustainable use of the nature for human wellbeing [29]. Various research approaches have been developed and applied to different studies in which the interaction between the social system and the ecological system has been explicitly considered [30-33]. These approaches include: (i) combining material or energy and economic flows [33-36]; (ii) modelling human behaviour and drivers that specifically impact on an ecosystem service [37,38]; (iii) identifying and modelling specific goods that are relevant for human and ecological systems [32]; and (iv) studying the resilience and adaptive management of social-ecological systems (SES) [39-41]. Concomitantly, frameworks have been developed to set a common language, to structure research on SES, and to provide guidance toward a more sustainable development of the social-ecological system. These frameworks differ significantly in their goals, their disciplinary background, their applicability, the temporal, social, and spatial scale addressed, and their conceptualization of the social and ecological systems as well as their interaction $[37,40,42-45]$. 
The social-ecological systems framework (SESF) is a combination of variables that have proven to be relevant for explaining sustainable outcomes in the management of forestry, fishery, and water resources $[30,43,44]$ The SESF includes in its conceptualization of the social system both the micro and macro levels, and also the interaction and feedback loops between them. In the SESF, social and governance structures affect the way in which the actors behave, and actors might be part of the governance system and shape it. The SESF explicitly includes dynamics in the social system. It conceptualizes the ecological system from an anthropocentric perspective: the ecological system is seen as a provider of services that increase human wellbeing. The SESF explicitly addresses the reciprocity between the social and the ecological systems $(S \leftrightarrow E)$. It also addresses interactions by defining the first-tier level variable "interactions". This generic category then provides second-tier level variables that allow further detailing, such as "harvesting rate", to represent how actors impact on the ecological system by using resources (S $\leftrightarrow \mathrm{E})$, and "sharing of information" to represent how actors assess the conditions of the resource $(E \rightarrow S)$. The SESF has been applied to study under what conditions the users of the resource develop rules for its sustainable management [30]. If the initial set of rules established by the users, or by a government, are not congruent with local resource conditions, long-term sustainability may not be achieved [44]. Studies suggest that long-term sustainability depends on rules matching the attributes of the resource system, resource units, and users, and also governance, i.e., the ability to apply the rules which are supposed to drive sustainability.

Based on the latter, the social-ecological systems framework (SESF) is arguably the most comprehensive conceptual framework for diagnosing interactions and outcomes in social-ecological systems [46]. The SES framework enables the integration of data from various natural and social science disciplines, thus providing a theoretically grounded means of testing hypotheses regarding the dynamics and implications of social-ecological interactions [46].

In a social-ecological system (SES), subsystems such as resource system (inland fisheries), resource units (pirogue, Acadja and other gears), users (fishers), and management systems (organizations and rules that governs fishing) are relatively separable but interact to produce outcomes at the SES level, which in turn affect the same subsystems and their components as well as other SESs [44]. The reciprocity between the social system and the ecological system includes feedback loops and learning processes in the social system in response to change. The SESF provides then a common language for the conceptualization of interactions within social-ecological system and their dynamics. The SESF relates concepts and variables where the ecological system is conceptualized from an anthropocentric perspective, which defines the ecological system based on its utility for humans as a resource system. The social system consists of resource users (fishers and their livelihoods), and the management system that influences actions by defining rules as well as monitoring and sanctioning mechanisms, all of which affect users' wellbeing as an outcome [30].

To assess a management subsystem from both social and ecological perspectives, it is necessary to identify some outcome variables (management system effect, common conditions trend, user group wellbeing) adapted from a specific natural system [47]. Indeed, at the fishers' level, there are non-monetary benefits gained from their activity, as job satisfaction, including attributes of adventure, challenge, and being outdoors, that are rarely found in other occupations $[22,48]$. Studies in the US have suggested that self-actualization (autonomy, independence), a component of job satisfaction, is responsible for adherence to the fishing profession, even in the face of declining income, and indicates a taste for adventure and risk-taking [24,49] Besides, for many fishers, professional attachment is developed and reinforced by family traditions and interactions with other fishers during and outside of working hours, as fishing is not seen as just a job [50,51] Moreover, job satisfaction is a major contributor to human wellbeing and therefore special attention must be paid to social groups whose survival depends on management decisions [27]. Wellbeing is a state of being with others, manifested by the satisfaction of human needs, 
where one can act usefully to pursue their goals and enjoy a satisfactory quality of life [52]. The purpose of job satisfaction research is to assess how management contributes to the wellbeing of fishers $[19,20]$. As such, dissatisfaction with the profession has been shown to create consequences for human wellbeing, including absenteeism, mental health illnesses, family violence, and longevity [53]. Additionally, the consideration of natural resources effect on user's wellbeing is seen as an integral part of conservation and maintenance strategies [54]. To sum up, efforts to sustainably manage inland fisheries could and should benefit from the use of robust indicators, to assess and compare the effects of environmental and management changes on fishers' wellbeing and to inform more effective and adaptive policy and management strategies [55]. Thus, optimal and sustainable management decision-making depends on the ability of managers to recognize and measure the individual and social non-monetary benefits of fishing [24,56]. A wellbeing approach can help recognize the difficult choices in sustainable fisheries management [57]. Figure 1 represents the attributes of socio-ecological systems and the relationships between them.

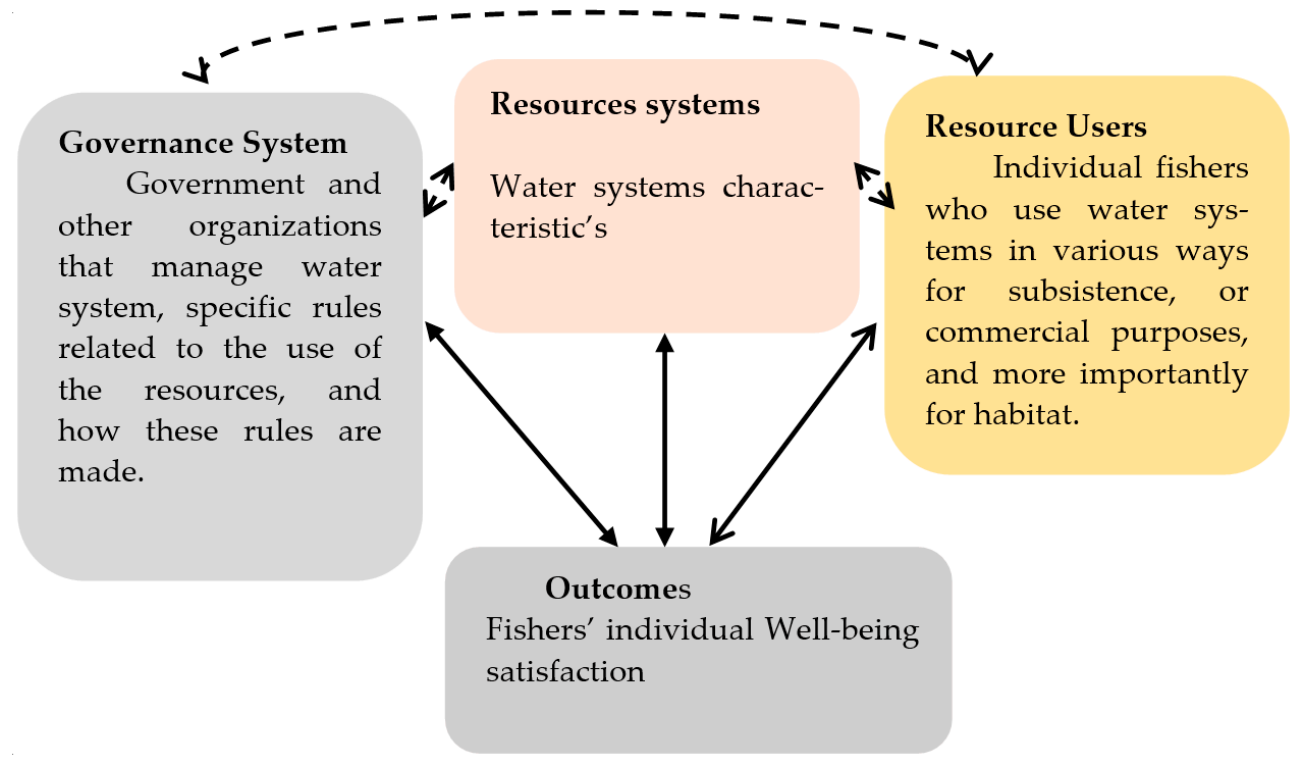

Figure 1. Social-ecological system attributes (Source: Adapted from Ostrom [44]).

\subsection{Evolution of Ecological Protection Rules in southern Benin}

In southern Benin, before the colonial period, resource management/conservation rules were introduced by the Houeda people's King. Among these rules, it was forbidden to jump into the lake at the risk of disturbing fish spawning grounds, to chase fish by hand to the fishing net, to put leaves in the water to attract fish, to use narrow-meshed fishing nets that contain hooks, and finally to fish two days a week in addition to the days of vodoun worship that protected the lake. Over time, the sanctions formerly applied to the rule's violators became no longer effective. By the end of the 1930s, all efforts to re-establish local institutions had failed [9]. During the period of colonization (1894-1960), regulation was not appropriate as local institutions were weakened [58]. From independence to the democratic period (1960 to 1990), various rules were instituted by the administrative authorities and essentially concerned the prohibition of Acadja in Lake Ahémé. In Lake Nokoué, on the other hand, the construction of Acadja was allowed but cannot be located anywhere on the water bodies. Since 2014, throughout Law N ${ }^{\circ} 2014-19$ of 7 August 2014, Acadja is prohibited. Despite this ban, the selection of locations for its implementation is governed by agreements between individuals, fishing communities, local authorities, but with very little public structure. This raises the low level of cooperation between fishers and public governance institutions [11]. 


\subsection{Study Area}

In southern Benin, there are two large estuarine and lagoon complexes, including Lake Nokoué lagoon of the Porto-Novo complex covering $180 \mathrm{~km}^{2}$ and forming part of Ramsar site 1018. It is supplied with fresh water by the Sô and Ouémé rivers. It is subject to marine influences through the channels of Cotonou and Badagry [59]. The two bodies of water maintain a permanent link through the $3 \mathrm{~km}$-long Totchè channel. The second, Lake Ahémé coastal lagoon complex covering $102 \mathrm{~km}^{2}$, is part of Ramsar site 1017. Lake Ahémé receives freshwater from the Couffo river and connects via the Aho channel to the coastal lagoon, whose hydrological regime is dependent on flooding from the Mono river and the upwelling of seawater through the Bouche du Roy river. This study focuses on fishers from the four most representative fishing activity towns in southern Benin. They include: (i) Aguégués and So-Ava in the southeast and closest to Lake Nokoué lagoon of the Porto-Novo complex; and (ii) Comè and Grand-Popo in the southwest closest to Lake Ahémé coastal lagoon complex (Figure 2). The choice of those towns met a certain number of criteria. They included: (i) the lakeside lifestyle, the so-called "Toffins" in the southeast (So-Ava, Aguégués) which contrasts with the land-based lifestyle, the so-called "Houeda" in the southwest (Comè, Grand-Popo); (ii) the large fishing populations of those towns; (iii) the diversity of the fishing gears/methods used; and (iv) the fact that they are each attached to a body of water making up the two estuarine and lagoon complexes. With these criteria, the study area covers the diversity of inland fishing issues in southern Benin [17].

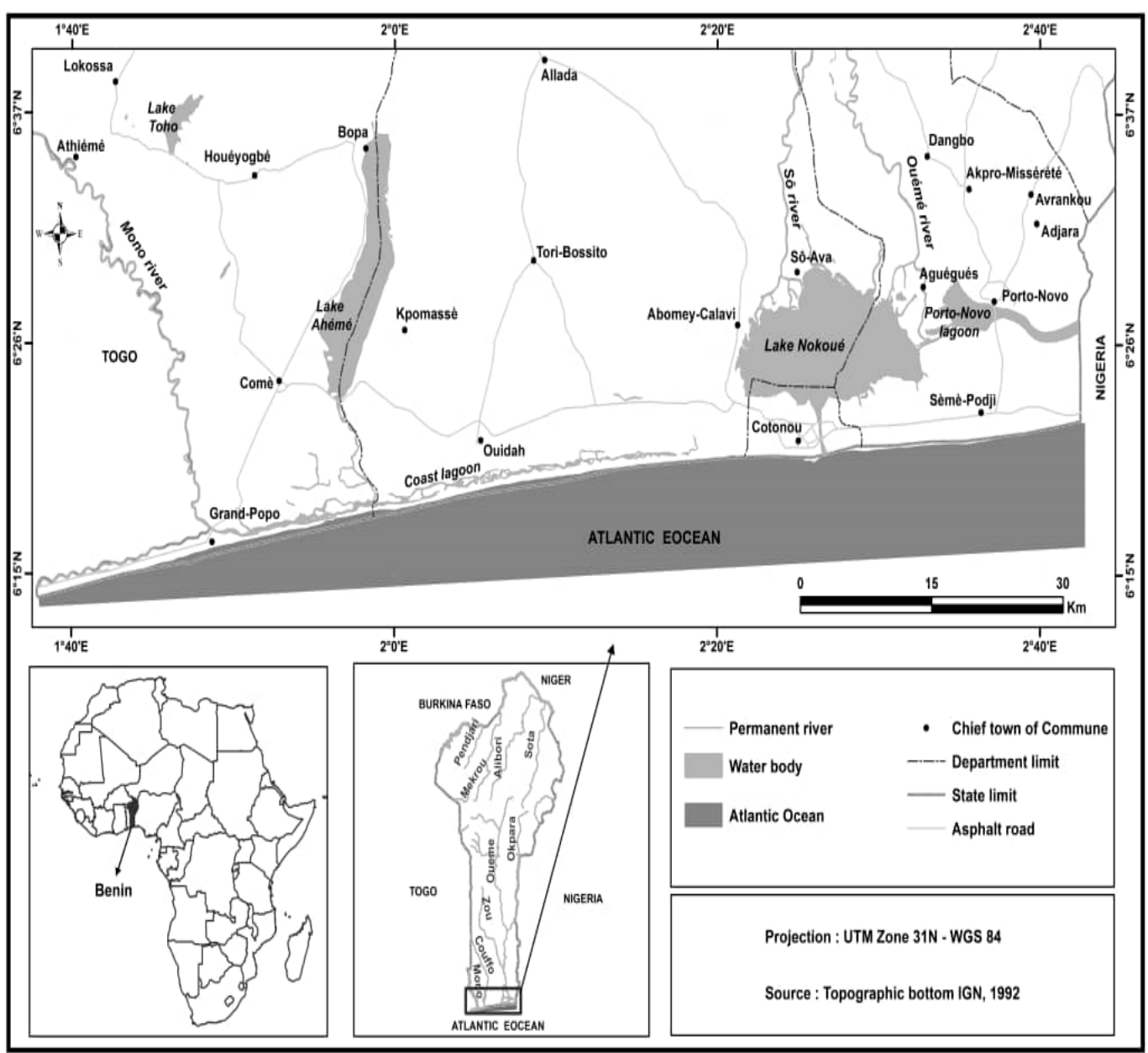

Figure 2. Map of the study area in southern Benin. Legend: bottom left: Benin is located in West Africa. The country is key-shaped and runs almost vertically from the Atlantic Coast in the south to the north. Bottom centre: the study zone is located in the south of Benin, along the coastal zone. Top: estuarine and lagoon complexes in blue with the survey towns around them. 


\subsection{Sampling}

Administratively, Benin is subdivided into 12 territorial departments; each department is subdivided into towns, each town into boroughs, and each borough into villages. The two lagoon and estuarine complexes of southern Benin cover 13 towns. For this study, it was decided to limit the number of towns in which fishing activity is well practiced in each complex of inland water bodies. Two towns were randomly selected in each complex. Consequently, the results of this study cannot be generalized for all of the communes of the two complexes but only to all the largest towns. The statistical units for this study are fishers. Within each selected town, two boroughs were randomly selected from all the boroughs in which fishing is practiced. Finally, within each selected borough, two villages were selected by a simple random draw from all the villages in which fishing is practiced. Exchanges with a certain number of resource persons made it possible to update this list in order to have an up-to-date sampling base. Thus, a certain number of fishers were selected by a simple random draw in each selected village. It is therefore a random sampling stratified by phases; each complex being considered as a stratum. The minimum size of fishers to be selected from each of these complexes was then determined independently. The estimation of the sample sizes was carried out in order to have reliable point estimates of the main relevant results within each complex. The sample size calculation formula used in this study is the Schwartz [60] formula. In total, 205 fishers were surveyed: 100 fishers for the Lake Nokoué Porto-Novo lagoon complex, and 105 fishers for the Lake Ahémé coastal lagoon complex.

\subsection{Data Collection}

The data collection was done via a questionnaire. Each subsystem is made up of multiple variables. Further, other variables contributing to fishers' wellbeing were also added to the questionnaire [21]. We assessed how this combination of factors can affect fishers' wellbeing. The questions addressed to the target population were organized into five sections, with each subsystem as follows:

\section{- $\quad$ Resource systems}

To characterize the resource systems, we collected data on clarity of system boundaries. We asked fishers if fishing boundaries are defined (yes or no) and if the boundaries are clear? (not clear, clear, very clear). Another question was in regard to Acadja ownership.

- Resource units

Resource units are fish. Most of data considered were secondary data collected by government service fisheries management. They included: resource unit mobility, growth or replacement rate, interaction among resource units, fish stocks, distinctive markings, and spatial and temporal distribution. Due to their unavailability, these data are not considered for the study.

\section{- Governance systems}

To characterize the governance systems, fishers were asked to report upon the regulations which had the greatest impact on their income. Regulations were classified into the categories of' "Acadja ban", "Mêdokpokonou ban", and "other regulations". They were also asked to report property rights systems and their co-management measures with government office in their area. As an indicator of management processes, fishers were asked to evaluate the clarity of regulations (unclear and clear). They were also asked to evaluate the impact of their individual and fishing associations participation to meetings on management and the influence these meetings have on the management plans developed, on scale of 1 to 3 (no impact or difference, to big impact or difference, with neutral).

- Users' demographic variables

The users' background information included age and fishing experience in years, education level, marital status, membership to fishery associations, and annual income from fishing and other activities. Further, based on the research tradition on job satisfaction 
in the fishing industry $[28,44,45]$ nine indicators for measuring job satisfaction used by Pollnac et al. [21] were used in this study (see Table 1). For each of the nine indicators, fishers were asked about their level of satisfaction on a scale from 1 to 5 , with 1 very dissatisfied, 5 very satisfied, and 3 neutral. These values are added up for each component of job satisfaction, which translated to a scale ranging from 3 to 15 , with a median of 9 .

Table 1. Three components of job satisfaction and the elements added to create them. Likert scale in parenthesis.

Basic needs (3-15)

Actual earnings from fishing (1-5)

Predictability of earnings from fishing (1-5) Safety of the job (1-5)

Social and psychological needs (3-15)

Fatigue from the job (1-5)

Healthiness of the job (1-5)

Time spent away from home (1-5)

Self-actualization (3-15)

Adventure of the job (1-5)

Challenge of the job (1-5)

Opportunity to be your own boss (1-5)

Source: Adapted from Pollnac et al. [21].

In addition, to analyse bundles of property rights, data were collected on various types of property rights (access, withdraw, management, exclusion, and alienation) and to characterize fishers' perceptions of ownership between the southeast and southwest in the study area.

- Wellbeing

Individual perceived wellbeing is the dependent variable in this study. Wellbeing is a multidimensional variable within which some, but not all, dimensions are interrelated [27]. Here, the focus is on one dimension of wellbeing: perceptions of individual wellbeing. The operationalization of this dimension of wellbeing is consistent with modern approaches to the variable [20,61] Previous analyses done by Oswald and $\mathrm{Wu}$ [61] have presented objective confirmation of responses to the subjective measure, "In general, how satisfied are you with your life?" for individual wellbeing. This question was evaluated on a 5-point Likert scale ranging from very dissatisfied to very satisfied. This method has been validated in the treatment of fishers' perceptions of wellbeing $[22,62,63]$

\subsection{Data Analysis}

Descriptive statistics were calculated for the variables of each subsystem. Analysis of the factors affecting overall variance in the individual perceived wellbeing of small-scale fishers was done in two steps. First, Likert scores were combined to gain better clarity on fishers' satisfaction [56]. Very dissatisfied and dissatisfied were combined to dissatisfied, while very satisfied and satisfied were combined to satisfied. Undecided choice was unaffected. In the second step, the testing of factors influencing fishers' individual perceived wellbeing satisfaction was done using ordered logistic regressions $[46,64]$. The choice of explanatory variables was dictated by the social-ecological system framework subsystems variables [45], following the literature.

The job satisfaction variables (basics needs, social and psychological needs, and selfactualization) were coded to $(0,1)$. Values below the median 9 (the satisfaction threshold) are coded 0 and values greater than or equal to 9 are coded 1 [22,26] For government governance clarity (5 Likert scale, very unclear to very clear), very unclear, unclear, and neutral were combined to unclear, while very clear and clear were combined to clear. For the fishers' power on governance (no one, neutral, high), no one and neutral were coded 0 , and high coded 1. Further, Spearman's rho correlation coefficient was used to measure the relationship between subsystem characteristics and individual perceived wellbeing [21]. 
According to Long and Freese [65], the ordered logistic general equation is expressed as follows:

$$
\mathrm{P}(\mathrm{Y} \leq \mathrm{j})=\frac{\exp \left[\alpha_{\mathrm{j}}+\left(\mathrm{B}_{1} \mathrm{X}_{1}+\ldots+\beta_{\mathrm{k}} \mathrm{X}_{\mathrm{k}}\right)\right]}{1+\exp \left[\alpha_{\mathrm{j}}+\left(\mathrm{B}_{1} \mathrm{X}_{1}+\ldots+\beta_{\mathrm{k}} \mathrm{X}_{\mathrm{k}}\right)\right]}
$$

where $P$ is the probability of predicting the $Y$ dependent variable with $j$ ordered levels, $X$ are the independent influencing covariates and factors described below (Table 2). The $Y$ dependent variable levels were specified as ordered: dissatisfied, undecided, and satisfied. Diagnostic tests were done to check assumptions of the ordered logistic regressions. The variance inflation factor (VIF) was calculated to detect multicollinearity between the explanatory variables of a model. Chatterjee et al. [66] underline that a multicollinearity problem is raised when a VIF has a value greater than or equal to 10, and/or when the mean VIF is greater than or equal to 2. In this research, the VIF calculation showed that multicollinearity was not a problem, as all VIFs were less than 10 and the mean VIF was 1.69. The assumption of proportional odds was also tested using a model function on STATA 15.1 [65]. The given results (likelihood ratio chi-square $=22.32$ with probability $=0.1728$ ) were not significant and indicated that the null hypothesis of no difference in the coefficients of model was accepted. Finally, in an ordered logistic model, marginal effects measure the expected change in the probability that a particular choice will be made relative to a unit change in an explanatory variable $[56,63]$. However, the marginal effects' signs and the respective coefficients may differ because the former depends on the sign and magnitude of all other coefficients [67]. All analysis was done with STATA 15.1 software.

Table 2. Definition of variables used in the ordered logistic regression model.

\begin{tabular}{|c|c|}
\hline Variables & Type of Variables/Description \\
\hline Acadja ownership & Categorical ( 1 if the fisher owns Acadja, 0 if not) \\
\hline Property ownership on water bodies & $\begin{array}{c}\text { Categorical ( } 1 \text { if the fishers believe they own space on the water bodies, } 0 \\
\text { if not) }\end{array}$ \\
\hline Household size & Continuous (number of household members) \\
\hline age & Continuous (age in year) \\
\hline Annual fishing income & Continuous \\
\hline Annual income from other activities & Continuous \\
\hline Basic needs & Categorical ( 1 if the value greater than or equal to 9,0 if not) \\
\hline Social and psychological needs & Categorical ( 1 if the value greater than or equal to 9,0 if not) \\
\hline Self-actualization & Categorical ( 1 if the value greater than or equal to 9,0 if not) \\
\hline Fishers power on government governance & $\begin{array}{c}\text { Categorical ( } 1 \text { if the fishers think their power on government governance } \\
\text { is high, } 0 \text { if not) }\end{array}$ \\
\hline Perceived effect of Acadja ban & $\begin{array}{c}\text { Categorical ( } 1 \text { if the fishers think the ban of Acadja has a negative impact } \\
\text { on fishing, } 0 \text { if not) }\end{array}$ \\
\hline Perceived effect of Mêdokpokonou ban & $\begin{array}{c}\text { Categorical (1 if the fishers think the ban of Mêdokpokonou has s } \\
\text { negative impact on fishing, } 0 \text { if not) }\end{array}$ \\
\hline Perception of government governance clarity & Categorical ( 1 if the fishers think government governance is clear, 0 if not) \\
\hline Perception of fishing boundary definitions & Categorical ( 1 if the fishers think boundaries are defined, 0 if not) \\
\hline $\begin{array}{l}\text { Perception of co-management measures with } \\
\text { government }\end{array}$ & Categorical ( 1 if the fishers think these measures exist, 0 if not) \\
\hline Fishing association membership & Categorical ( 1 if the fisher is a member of a fishing association, 0 if not) \\
\hline Marital status & Categorical ( 1 if the fisher is married, 0 if not) \\
\hline
\end{tabular}

\section{Results}

\subsection{Description of Social-Ecological Subsystem Variables}

The social-ecological subsystems as described above have many variable components (Table 3). First, in the resource's subsystem, to the question of whether fishing boundaries are defined in the estuarine and lagoon environments of southern Benin, $77 \%$ of the study respondents answered negatively. This result implies the occurrence of regular intrusions into areas traditionally belonging to other fishing communities. Regarding governance subsystem characteristics, respondents were asked to identify regulations 
that had a negative impact on income. If a given regulation type was mentioned in response, it was coded as present; hence, the relationships examined are between two dichotomous variables. The "ban of Acadja" (34\%) and "ban of Mêdokpokonou" (42\%) are the regulations which have the most impact on the income of the fishers. Other regulations $(23 \%)$ related to closure of the Cotonou and Grand-Popo mouths and "ban of some days on the water" were also mentioned by fishers. Besides, $65 \%$ of fishers perceived that government regulations are not clear, while $62 \%$ of them estimated that they could not influence the government management process. This result shows that fishers were not probably involved in the definition of these rules.

Concerning users' demographic characteristics, the age distribution of the fishers showed that over $16 \%$ of the sample were young (between 21 and 35 years old), 35\% were between 35 and 50 years old, while $49 \%$ were over 50 years old. The number of fishing experience in years was between 26 and 50 years for about $52 \%$ of the surveyed fishers. In addition, $52 \%$ of fishers had no level of education, $30 \%$ had primary school level, while $62 \%$ were not members of any professional fishers' association. Further, $62 \%$ of the surveyed fishers were satisfied that their social and psychological needs were being med, $63 \%$ were satisfied about self-actualization, and $68 \%$ about basics needs.

Table 3. Descriptive statistics of the social-ecological system framework subsystem variables.

\begin{tabular}{|c|c|c|}
\hline \multicolumn{2}{|c|}{ Variables } & $\%$ \\
\hline \multicolumn{3}{|c|}{ Resource subsystem variables } \\
\hline \multirow{2}{*}{ Are fishing boundaries defined? } & No & 77 \\
\hline & Yes & 23 \\
\hline \multicolumn{3}{|c|}{ Governance subsystem variables } \\
\hline \multirow{4}{*}{$\begin{array}{l}\text { Regulations that had the greatest impact } \\
\text { on their income }\end{array}$} & Ban on Acadja & 34 \\
\hline & Ban on Mêdokpokonou & 42 \\
\hline & Ban on some days on the water & 0.5 \\
\hline & Other regulations & 23 \\
\hline \multirow{4}{*}{$\begin{array}{l}\text { Perception of clarity of government } \\
\text { regulations } \\
\text { Do fishermen have relative power over } \\
\text { the governance process? }\end{array}$} & Regulations are not clear & 35 \\
\hline & Regulations are clear & 65 \\
\hline & No power on governance process & 62 \\
\hline & Power on governance process & 38 \\
\hline \multirow{2}{*}{$\begin{array}{l}\text { Co-management measures with } \\
\text { government }\end{array}$} & No & 82 \\
\hline & Yes & 18 \\
\hline \multicolumn{3}{|c|}{ Users' characteristics } \\
\hline \multirow{4}{*}{ Age distribution } & $(21-35)$ & 16 \\
\hline & $(35-50)$ & 35 \\
\hline & $\leq 50$ & 49 \\
\hline & $(1-250$ & 28 \\
\hline \multirow[t]{3}{*}{ Fishing experience } & $(26-50)$ & 52 \\
\hline & $>50$ & 20 \\
\hline & None & 52 \\
\hline \multirow[t]{2}{*}{ Education level } & Primary & 33 \\
\hline & Secondary & 15 \\
\hline \multirow{2}{*}{ Fishing association membership } & No & 61 \\
\hline & Yes & 39 \\
\hline \multirow{2}{*}{ Marital status } & Married & 98 \\
\hline & Single & 2 \\
\hline \multirow{2}{*}{ Basics needs satisfaction } & $<9$ & 32 \\
\hline & $(9-15)$ & 68 \\
\hline \multirow{2}{*}{$\begin{array}{l}\text { Social and psychological needs } \\
\text { satisfaction }\end{array}$} & $<9$ & 38 \\
\hline & $(9-15)$ & 62 \\
\hline \multirow{2}{*}{ Self-actualization satisfaction } & $<9$ & 37 \\
\hline & $(9-15)$ & 63 \\
\hline
\end{tabular}


Finally, $82 \%$ of the fishers affirmed the non-existence of co-management measures of property rights with the government offices.

As regards property rights, it is important to stress that in addition to the subsistence and commercial rights detained by fishers, the population of fishers have established their habitat in the southeast. The analysis of the bundles of property rights (Table 4) reveals that access and extraction rights are equally distributed among fishers in both areas. The fishers can therefore access and fish for their daily needs. However, in the southeast, in addition to access and extraction rights, there are management, exclusion, and alienation rights to the water bodies. These particular property rights are owned by fishing families. They are used for the construction of dwellings in view of the lake lifestyle, but also for the installation of Acadja for fish production. In the southeast, the perception of the water body goes beyond simple grazing but is considered a living space that fishers, appropriate for their survival and transferable to future generations.

Table 4. Property right bundles.

\begin{tabular}{ccccc}
\hline \multirow{2}{*}{ Property Right Bundles } & \multicolumn{2}{c}{ Southeast } & \multicolumn{2}{c}{ Southwest } \\
\cline { 2 - 5 } & Aguégués & Sô-Ava & Comè & Grand-Popo \\
\hline Access & $42 \%$ & $32 \%$ & $49 \%$ & $49 \%$ \\
Withdrawal & $44 \%$ & $32 \%$ & $49 \%$ & $51 \%$ \\
Management & $10 \%$ & $15 \%$ & $2 \%$ & $0 \%$ \\
Exclusion & $1 \%$ & $7 \%$ & $0 \%$ & $0 \%$ \\
Alienation & $4 \%$ & $13 \%$ & $0 \%$ & $0 \%$ \\
\hline
\end{tabular}

\subsection{Factors Affecting Fishers Individual Perceived Wellbeing Satisfaction}

Table 5 presents the results of the ordered logistic regression with the variables that significantly affect fishers' individual perceived wellbeing satisfaction. The likelihood ratio chi-square of 184.02 with a $p$-value of 0.00 indicated that the model as a whole is statistically significant, as compared to the null model with no predictors. The pseudo- $\mathrm{R}^{2}$ indicates that about $51 \%$ of variance in the reported wellbeing is attributable to the combination of the significant effects $(p<0.05$ at least) of six out of the seventeen variables included in the model. The variables such as Acadja ownership, household size, fishers' age, fishers' power on governance, government governance clarity, fishing boundary definitions, annual fishing income, annual other activities income, co-management measures with government, fishing association membership, and marital status do not have significant coefficients and thus do not contribute to the variance of fishers' individual wellbeing. The coefficient of variables such as property ownership on water bodies, basics needs satisfaction, social and psychological needs satisfaction, and self-actualization satisfaction are positive and increase fishers' individual wellbeing satisfaction. The coefficient of variables such as Acadja and Mêdokpokonou bans are negatives and decrease fishers' individual wellbeing satisfaction. Fishers' perceived wellbeing satisfaction is also positively affected by property ownership because as this allows for the setting up and operating of Acadja, increasing fishing income.

The three components of job satisfaction are statistically significant, as expected. The statistically significant positive coefficient associated with basics needs satisfaction indicated that fishers' individual wellbeing is directly linked to the satisfaction of earning from fishing. Concerning social and psychological satisfaction variable, its coefficient is positive and significant. This suggests that fishers are satisfied with the time they spend away from home, the fatigue, and the healthiness of the job. The same result could be observed with self-actualization, suggesting that fishers are satisfied with the adventure, challenge, and opportunity offered by fishing activities.

However, the statistically significant negative coefficients associated with the ban on Acadja and Mêdokpokonou suggest that fishers' individual wellbeing satisfaction decreases with the bans as they negatively impact fishers' income. 


\subsection{Marginal Effects of Factors Affecting Fishers's Wellbeing}

The marginal effects of the explanatory variables determining fishers' individual wellbeing satisfaction are calculated to better understand the impact of these variables (Table 5). An increase in the perception of the existence of property ownership on the water bodies of one unit leads to a 0.265 increase in the fishers' individual wellbeing satisfaction. When fishers' perception about their satisfaction of basics needs (earnings), social and psychological needs, and self-actualization increase by one unit, the probability of fishers' individual wellbeing satisfaction increases respectively by $0.457,0.235$, and 0.646 . Conversely, when the perception of the effects of the Acadja and Mêdokpokonou bans on fishing income increase by one unit, the probability of fishers' individual wellbeing satisfaction decreases by 0.424 and 0.304 , respectively.

Table 5. Ordered regression between independent variables and wellbeing with marginal effects.

\begin{tabular}{cccc}
\hline Variables & Coef. & St. Err. & Marginal Effects \\
\hline Property ownership on water bodies & $1.384^{* *}$ & 0.660 & $-0.265^{* *}$ \\
Basic needs satisfaction & $2.119^{* * *}$ & 0.547 & $-0.457^{* * *}$ \\
Social and psychological needs & $1.117^{* *}$ & 0.538 & $-0.235^{* *}$ \\
satisfaction & $3.249^{* * *}$ & 0.582 & $-0.646^{* * *}$ \\
Self-actualization satisfaction & $-1.983^{* *}$ & 0.893 & $0.424^{* *}$ \\
Acadja ban & $-1.474^{*}$ & 0.761 & $0.304^{* *}$ \\
Mêdokpokonou ban & 0.506 & Number of observations & 203.000 \\
Pseudo r-squared & 184.022 & Prob $>$ chi ${ }^{2}$ & 0.000 \\
\hline Likelihood ratio Chi-square & &
\end{tabular}

$* * *, * *, *$, respectively, represent statistical significances at levels of $1 \%, 5 \%$, and $10 \%$.

\section{Discussion}

The present study evaluated fishers' perceptions of their individual wellbeing satisfaction within the social-ecological fisheries system located in the estuarine and lagoon area in southern Benin. Based on the social-ecological system framework, the different subsystems variables were identified, described, and analysed with an ordered logistic regression model.

The results show that fishing boundaries were not clear and that fishers were probably not involved in the definition of these rules. These contacts do not encourage the sustainable management of resources. These results are in line with the authors of $[64,68]$ who underlined that the definition of boundaries and the participation of fishers in the establishment of rules are principles of sustainable collective action. Otherwise, the bundles of property rights observed on both sides of the study area show a difference in perception between the fishers. In the southwest, where fishers consider the water body as a pasture from which fish can be taken for survival, it is possible to apply the collective action advocated by Ostrom [69] in order to guarantee the sustainability of resource exploitation. However, in the southeast, where water bodies are perceived as a living space in addition to their grazing attributes, is collective action still a panacea? Shouldn't specific forms of management be considered that involve the perception of living space that fishers give to these environments?

Actually, the results from the regression did not show evidence of the contribution of some variables related to the governance subsystem and characteristics of the user. For instance, fishing boundary definitions and/or a resources subsystem variable does not contribute to fishers' individual wellbeing satisfaction. By referring to Table 3, this result could express that the existence of fishing boundaries between communities would make it possible to limit various intrusions and thus preserve resources of each fishing area. Moreover, the absence of the co-management of property rights with government does not favour the sustainable management of fishing ecosystems in southern Benin. These results are similar to those of Sonneveld et al. [11] who demonstrated that fishing boundaries are 
not defined in southern Benin. Furthermore, the authors underline that there is no joint responsibility for resources governance in fishing areas of southern Benin as required by Ostrom's eight prerequisites for the sustainable and equitable development of common resources. Indeed, according to Ostrom [70], a clear definition of fishing boundaries is one of the principles supposed to increase probability of sustained collective action through the creation of conditions that encourage users to cooperate with institutions of common property; from this cooperation the fishers' satisfaction about individual wellbeing could therefore arise. Regarding the governance subsystem variables, the power of fishers over governance is not significant and expresses that the participation of fishers in governance processes does not influence water management decisions and therefore does not contribute to their wellbeing.

In addition, the government's governance rules are not sufficiently clear to fishers to contribute to the satisfaction of their individual wellbeing. Indeed, in participating in governance processes, fishers indicated that they would have made proposals for measures that could improve their fishing conditions and probably contribute to the sustainable management of fisheries. When these measures are not considered, fishers have the perception of being neglected, what may affect their individual wellbeing satisfaction. This result is consistent with the results of [71] which affirmed that co-management is generally believed to be the preferred approach for sustainability.

However, the results also show that ownership of water bodies positively contributes to fishers' individual wellbeing. Indeed, ownership allows Acadja settling, which is a source of increased income. Given certain historical factors in the settlement of their families, some influential fishers monopolize spaces on the bodies of water [12]. As a result, many other fishers have lost their rights to fish around areas under Acadja. They are therefore constrained to rent the spaces for fishing, which constitutes additional charges. This ownership creates some social equity problems between fishers operating in the same areas [72]. It is also a contradiction among water resource sustainability. This result is similar to those of Keyzer et al. [73], which affirm that lakes must be considered as open access resources with no exercise of property rights.

The negative influence of the Acadja and Mêdokpokonou ban on fishers' individual wellbeing satisfaction indicates their attachment to this fishing gear and method. This attachment results from Acadja's selectivity for certain fish species that account for nearly $95 \%$ of total fish numerical abundance in Lake Nokoué [16]. Acadja becomes then financially profitable for fishers and its ban creates income reduction, thus explaining their individual wellbeing dissatisfaction. The "laisser-aller" that follows the ban offers to certain participants the occasion to continue the use of this fishing gear, while others who are more respondent to government regulations, see their wellbeing decrease. The bans are scarcely followed with monitoring. Thus, the records of replenishment and pollution followed by the overexploitation of Lake Nokoué by fishing gear and techniques such as Mêdokpokonou and Acadja threaten biological diversity [74].

The results showed that the three components of job satisfaction (basic needs, social and psychological needs, and self-actualization) positively influence fishers' individual wellbeing satisfaction. These results indicate the therapeutic value of fishing, reflected in the job satisfaction scores (see Table 3), which positively influence fishers' lives [22] when compared to the relationship between subjective job satisfaction and fishers' individual wellbeing variables in US Northeast Region and Southeast Puerto Rico. As a precursor of research on this theme, Pollnac et al. [19] affirmed that job satisfaction components are linked to individual wellbeing satisfaction, as when fishers are satisfied with their occupation it can result in improved feelings of wellbeing. Standards of living, reflecting the general comfort in which households live (housing, possession of durable goods, and hygiene), declined by $2.6 \%$ (value of $26.1 \%$ ) in 2019 compared to 2015 when it was $28.7 \%$ [75]. Furthermore, although rural areas are more affected by non-monetary poverty, rural households experienced an improvement in their conditions in 2019 compared to 2015 (the incidence fell from $36.0 \%$ to $28.6 \%$ ). The gradual decline in non-monetary poverty 
in recent years is a sign of improved access to basic infrastructure. These conditions may also contribute to the fishers' job satisfaction and de facto to the positive perception of their individual wellbeing. The study area is projected to have a population that has grown from 2,995,876 in 2013 to around 3,890,149 in 2019. Aside from fishing, this population is mainly active in food crop production (maize, cassava, cowpeas, and ground-nuts) and small-scale pig and poultry farming. The crucial problem in the area remains the availability of agricultural land, as the area of cultivable land is shrinking over time due to urbanization. Fallow land is practically non-existent and the cultivation system is hardly improving as soils are being degraded by overexploitation [76].

Nevertheless, this wellbeing satisfaction will be severely tested in view of the degradation of catch levels resulting from climate change and overfishing, but also in light of the reforms underway in the fisheries sector in Benin. Fishers' perception of the government governance could influence job satisfaction, influencing wellbeing satisfaction [28]. Finally, the good governance of resources means regulation and control of fishers' social action by credible institutions, appropriate texts, and resources to accomplish the public policy [77]. This is not the case in southern Benin. It follows that poor governance of resources results in the persistence of overfishing, which locks the fishers into a vicious circle of poverty [78].

Therefore, it seems imperative that fishers be involved in governance strategy design processes in order to understand them well, adopt them, and then monitor their implementation. This requires the timely dissemination of information to fishers, the delegation of responsibilities and power, the decentralization of decision-making to consider local contexts.

\section{Conclusions}

The present study aims at showing how the satisfaction of the fishermen's wellbeing can be considered a result of the socio-ecological system in the estuarine and lagoon environments of southern Benin. Though ecological data was unavailable, our results showed that job satisfaction and ownership have significant roles in the fishers' perception of their individual wellbeing satisfaction. However, the bans on some fishing gear (Acadja and Mêdokpokonou) drastically decrease fishers' individual wellbeing. Moreover, the lack of clarity in government regulations and absence of co-management measures with government contribute poorly to fishers' individual wellbeing. It is therefore appropriate to involve fishers in rules regarding prohibited gear (Acadja and Mêdokpokonou) and ownership management, and also to understand resource stocks in order to anticipate their evolution alongside an increasing demography. For this it is necessary to evaluate the scenarios of eco-sustainability of artisanal fisheries and to decentralize the decision-making process in order to involve the fishers in the implementation of the recommendations.

Author Contributions: All authors were involved in preparing the manuscript. Conceptualization, S.B.-V.K.K., H.D. and T.D.; methodology, S.B.-V.K.K., H.D., T.D., S.K.C. and A.K.N.A.; software, S.B.-V.K.K., H.D. and T.D.; validation, S.B.-V.K.K., T.D., H.D., S.K.C. and. A.K.N.A.; formal analysis, S.B.-V.K.K., H.D. and T.D.; investigation, S.B.-V.K.K., H.D. and T.D.; resources, S.B.-V.K.K., H.D. and T.D.; data curation, S.B.-V.K.K., H.D. and T.D.; writing—original draft preparation, S.B.-V.K.K., H.D. and T.D. writing-review and editing, S.B.-V.K.K., T.D., H.D., S.K.C. and. A.K.N.A.; visualization, S.B.-V.K.K., T.D., H.D., S.K.C. and. A.K.N.A.; supervision, H.D. and T.D. All authors have read and agreed to the published version of the manuscript.

Funding: This research received no external funding.

Acknowledgments: The authors are grateful to fishers who provided the collected data.

Conflicts of Interest: The authors declare no conflict of interest. 


\section{References}

1. FAO. La Situation Mondiale des Pêches et de L'aquaculture 2018. Atteindre les Objectifs de Développement Durable; FAO: Rome, Italy, 2018.

2. Bennett, A.; Patil, P.; Kleisner, K.; Rader, D.; Virdin, J.; Basurto, X. Contribution of Fisheries to Food and Nutrition Security Current Knowledge, Policy, and Research; Nicholas Institute, Duke University: Durham, UK, 2018.

3. Lalmalsawmzauva, K.C.; Sati, V.P. Natural Resources Management for Sustainable Development and Rural Livelihoods Vol-1; Today and Tomorrow's Printers and Publishers: New Delhi, India, 2017; ISBN 1555284345.

4. Léopold, M. Exploration de la Performance de la Gouvernance des Petites Pêcheries du Pacifique Sud par une Démarche de Recherche-Action. Ph.D. Thesis, Economies et Finances, Université de Bretagne Occidentale, Brest, France, 2018.

5. Russi, D.; Brink, P.T.; Farmer, A.; Badura, T.; Coates, D.; Förster, J.; Kumar, R.; Davidson, N. The Economics of Ecosystems and Biodiversity for Water and Wetlands. Final Consultation Draft; IUCN: Gland, Switzerland, 2012.

6. Njiru, M.; van der Knaap, M.; Taabu-Munyaho, A.; Nyamweya, C.S.; Kayanda, R.J.; Marshall, B.E. Management of Lake Victoria fishery: Are we looking for easy solutions? Aquat. Ecosyst. Health Manag. 2014, 17, 70-79. [CrossRef]

7. Daouda, A.M.; Gangbazo, H.K.; Hounkpatin, F.C.; Ogou, J.A. Evaluation de la Production Halieutique Pour le Rebasage des Comptes Nationaux et Passage au Système des Comptes Nationaux; Ministère de l'Agriculture de l'Elevage et de la Pêche: Cotonou, Bénin, 2018.

8. Pierre, F.; El Ayoubi, H. Industrie des Pêches et de l'Aquaculture au Bénin; COMHAFAT: Rabat, Morocco, 2015.

9. Pliya, J. La Pêche Dans le Sud-Ouest du Bénin. Étude de Géographie Appliquée sur la Pèche Continentale et Maritime; Agence de Coopération Culturelle et Technique: Paris, France, 1980.

10. Sidi, L. Contribution à L'étude de la Pêche Continentale en République Populaire du Bénin. Ph.D. Thesis, Université de Dakar, Dakar, Senegal, 1981.

11. Sonneveld, B.; Thoto, F.; Houessou, D.; van Wesenbeeck, L. The tragedy of the inland lakes. Int. J. Commons 2019, 13, 609-636. [CrossRef]

12. Kpanou, S.B.-V.K.; Dedehouanou, H.; Chogou, S.K.; Aoudji, A.K.N.; Dogot, T. Factors Influencing Small-Scale Fishers' Individual Perceived Wellbeing Satisfaction in Southern Benin. Sustainability 2021, 13, 6279. [CrossRef]

13. Rurangwa, E.; van den Berg, J.; Laleye, P.A.; van Duijn, A.P.; Rothuis, A. Mission Exploratoire Pêche, Pisciculture et Aquaculture au Bénin un Quick Scan du Secteur Pour des Possibilités D'interventions; Institute for Marine Resources \& Ecosystem Studies, IMARES, Wageningen University and Research: Wageningen, The Netherlands, 2014.

14. Gnakadja, G. Assistance à L'élaboration d'un Schéma Directeur du Secteur de Développement Agricole et Rural: Rapport du Consultant National sur les Pêches Continentales et Aquaculture (Rédigé Après la Tenue des Ateliers Départementaux); Ministère du Developpement Rural: Cotonou, Bénin, 2000.

15. Lalèyè, P.; Vandewalle, P.; Philippart, J.-C.; Teugels, G. Caractéristiques de la pêche dans le fleuve Ouémé au Bénin (Afrique de l'Ouest). In Proceedings of the Third international conference on African fish and fisheries Cotonou, Benin, 10-14 November 2003; Royal Museum for Central Africa: Tervuren, Belgium, 2003; p. 216.

16. Niyonkuru, C.; Lalèyè, P.A. Impact of acadja fisheries on fish assemblages in Lake Nokoué, Benin, West Africa. Knowl. Manag. Aquat. Ecosyst. 2010, 5, 1-15. [CrossRef]

17. Stoop, N.; Houssa, R.; Verpoorten, M. To Fish or Not to Fish? Resource Degradation and Income Diversification in Benin. Environ. Dev. Econ. 2016, 21, 669-689. [CrossRef]

18. Briones Alonso, E.; Houssa, R.; Verpoorten, M. Voodoo versus fishing committees: The role of traditional and contemporary institutions in fisheries management. Ecol. Econ. 2016, 122, 61-70. [CrossRef]

19. Pollnac, R.B.; Abbott-Jamieson, S.; Smith, C.; Miller, M.L.; Clay, P.M.; Oles, B. Toward a model for fisheries social impact assessment. Mar. Fish. Rev. 2006, 68, 1-18.

20. Himes-Cornell, A.; Kasperski, S. Using Socioeconomic and Fisheries Involvement Indices to Understand Alaska Fishing Community Well-Being. Coast. Manag. 2016, 44, 36-70. [CrossRef]

21. Pollnac, R.B.; Seara, T.; Colburn, L.L. Aspects of Fishery Management, Job Satisfaction, and Well-Being among Commercial Fishermen in the Northeast Region of the United States. Soc. Nat. Resour. 2015, 28, 75-92. [CrossRef]

22. Seara, T.; Pollnac, R.B.; Poggie, J.J.; Garcia-Quijano, C.; Monnereau, I.; Ruiz, V. Fishing as therapy: Impacts on job satisfaction and implications for fishery management. Ocean Coast. Manag. 2017, 141, 1-9. [CrossRef]

23. Armitage, D.; Béné, C.; Charles, A.T.; Johnson, D.; Allison, E.H. The interplay of well-being and resilience in applying a socialecological perspective. Ecol. Soc. 2012, 17. [CrossRef]

24. Pollnac, R.B.; Poggie, J.J. Happiness, Well-being and Psychocultural Adaptation to the Stresses Associated with Marine Fishing. Hum. Ecol. Rev. 2008, 15, 194-200.

25. Pollnac, R.B.; Colburn, L.L.; Seara, T.; Weng, C.; Yentes, K.; Job Satisfaction, Wellbeing, and Change in Southern New England Fishing Communities. Technical Report Developed for the Commercial Fisheries Research Foundation. 2011. Available online: http:/ / www.nefsc.noaa.gov/read/socialsci/pdf/publications/Job-Satisfaction_FinalRpt_REVISED.p (accessed on 10 May 2021).

26. Seara, T.; Pollnac, R.B.; Poggie, J.J. Changes in Job Satisfaction Through Time in Two Major New England Fishing Ports. J. Happiness Stud. 2017, 18, 1625-1640. [CrossRef]

27. Satumanatpan, S.; Pollnac, R. Factors influencing the well-being of small-scale fishers in the Gulf of Thailand. Ocean Coast. Manag. 2017, 142, 37-48. [CrossRef] 
28. Pollnac, R.B.; Carothers, C.; Seara, T.; Poggie, J.J. Evaluating impacts of marine governance on human communities: Testing aspects of a human impact assessment model. Environ. Impact Assess. Rev. 2019, 77, 174-181. [CrossRef]

29. Kareiva, M.M.P. What is conservation science? Bioscience 2012, 62, 962-969. [CrossRef]

30. Binder, C.R.; Hinkel, J.; Bots, P.W.G.; Pahl-Wostl, C. Comparison of frameworks for analyzing social-ecological systems. Ecol. Soc. 2013, 18. [CrossRef]

31. Young, O.R.; Berkhout, F.; Gallopin, G.C.; Janssen, M.A.; Ostrom, E.; van der Leeuw, S. The globalization of socio-ecological systems: An agenda for scientific research. Glob. Environ. Chang. 2006, 16, 304-316. [CrossRef]

32. Liu, J.; Dietz, T.; Carpenter, S.R.; Folke, C.; Alberti, M.; Redman, C.L.; Schneider, S.H.; Ostrom, E.; Pell, A.N.; Lubchenco, J.; et al. Coupled human and natural systems. Ambio 2007, 36, 639-649. [CrossRef]

33. Binder, C.R. From material flow analysis to material flow management Part I: Social sciences modeling approaches coupled to MFA. J. Clean. Prod. 2007, 15, 1596-1604. [CrossRef]

34. Duchin, F.; Steenge, A.E. Input-Output Analysis, Technology and the Environment. In Handbook of Environmental and Resource Economics; van den Bergh, J.C.J.M., Ed.; Edward Elgar Publishing: Cheltenham, UK, 1999; p. 1328, ISBN 9781858983752.

35. Bouman, M.; Heijungs, R.; Van Der Voet, E.; Van Den Bergh, J.C.J.M.; Huppes, G. Material flows and economic models: An analytical comparison of SFA, LCA and partial equilibrium models. Ecol. Econ. 2000, 32, 195-216. [CrossRef]

36. Kytzia, S.; Faist, M.; Baccini, P. Economically extended-MFA: A material flow approach for a better understanding of food production chain. J. Clean. Prod. 2004, 12, 877-889. [CrossRef]

37. Redman, C.L. Human dimensions of ecosystem studies. Ecosystems 1999, 2, 296-298. [CrossRef]

38. Antle, J.M.; Stoorvogel, J.J. Predicting the supply of ecosystem services from agriculture. Am. J. Agric. Econ. 2006, 88, 1174-1180. [CrossRef]

39. Folke, C.; Carpenter, S.; Elmqvist, T.; Gunderson, L.; Holling, C.S.; Walker, B. Resilience and sustainable development: Building adaptive capacity in a world of transformations. AMBIO 2002, 31, 437-440. [CrossRef]

40. Holling, C.S.; Allen, C.R. Adaptive inference for distinguishing credible from incredible patterns in nature. Ecosystems 2002, 5, 319-328. [CrossRef]

41. Walker, B.; Carpenter, S.; Anderies, J.; Abel, N.; Cumming, G.; Janssen, M.; Lebel, L.; Norberg, J.; Peterson, G.D.; Pritchard, R. Resilience management in social-ecological systems: A working hypothesis for a participatory approach. Ecol. Soc. 2002, 6. [CrossRef]

42. Gallopín, G.C.; Funtowicz, S.; O'Connor, M.; Ravetz, J. Science for the twenty-first century: From social contract to the scientific core. Int. Soc. Sci. J. 2001, 53, 219-229. [CrossRef]

43. Ostrom, E. A diagnostic approach for going beyond panaceas. Proc. Natl. Acad. Sci. USA 2007, 104, 15181-15187. [CrossRef]

44. Ostrom, E. A General Framework for Analyzing Sustainability of Social-Ecological Systems. Science 2009, 325, 419-422. [CrossRef]

45. Pahl-Wostl, C. A conceptual framework for analysing adaptive capacity and multi-level learning processes in resource governance regimes. Glob. Environ. Chang. 2009, 19, 354-365. [CrossRef]

46. Leslie, H.M.; Basurto, X.; Nenadovic, M.; Sievanen, L.; Cavanaugh, K.C.; Cota-Nieto, J.J.; Erisman, B.E.; Finkbeiner, E.; HinojosaArango, G.; Moreno-Báez, M.; et al. Operationalizing the social-ecological systems framework to assess sustainability. Proc. Natl. Acad. Sci. USA 2015, 112, 5979-5984. [CrossRef] [PubMed]

47. Aguilera, S.E. Measuring squid fishery governance efficacy: A social-ecological system analysis. Int. J. Commons 2018, 12, 21-57. [CrossRef]

48. Apostle, R.; Kasdan, L.; Hanson, A. Work Satisfaction and Community Attachment among Fishermen in Southwest Nova Scotia. Can. J. Fish. Aquat. Sci. 1985, 42, 256-267. [CrossRef]

49. Pollnac, R.B.; Poggie, J.J. Job satisfaction in the fishery in two Southeast Alaskan towns. Hum. Organ. 2006, 65, 329-339. [CrossRef]

50. Marshall, N.A.; Fenton, D.M.; Marshall, P.A.; Sutton, S.G. How Resource Dependency Can Influence Social Resilience within a Primary Resource Industry. Rural Sociol. 2007, 72, 359-390. [CrossRef]

51. Pascoe, S.; Cannard, T.; Jebreen, E.; Dichmont, C.M.; Schirmer, J. Satisfaction with fishing and the desire to leave. AMBIO 2015, 44, 401-411. [CrossRef]

52. McGregor, A. Well-Being, Poverty and Conflict. B, ESRC Research Group on Well-Being in Developing Countries; University of Bath: Bath, UK, 2008.

53. Smith, C.L.; Clay, P.M. Measuring subjective and objective well-being: Analyses from five marine commercial fisheries. Hum. Organ. 2010, 69, 158-168. [CrossRef]

54. Daw, T.M.; Hicks, C.C.; Brown, K.; Chaigneau, T.; Januchowski-Hartley, F.A.; Cheung, W.W.L.; Rosendo, S.; Crona, B.; Coulthard, S.; Sandbrook, C.; et al. Elasticity in ecosystem services: Exploring the variable relationship between ecosystems and human well-being. Ecol. Soc. 2016, 21, 13. [CrossRef]

55. Partelow, S. Key steps for operationalizing social - ecological system framework research in small-scale fi sheries: A heuristic conceptual approach. Mar. Policy 2015, 51, 507-511. [CrossRef]

56. Kimani, P.; Wamukota, A.; Manyala, J.O.; Mlewa, C.M. Actors' perceptions of government performance in support of value chain development in marine small-scale fisheries in Kenya. Mar. Policy 2020, 104221. [CrossRef]

57. Coulthard, S.; Johnson, D.; Mcgregor, J.A. Poverty, sustainability and human wellbeing: A social wellbeing approach to the global fisheries crisis. Glob. Environ. Chang. 2011, 21, 453-463. [CrossRef] 
58. Dangbégnon, C. Governing local commons What can be learned from the failures of lake Aheme's institutions in Benin. In Proceedings of the Eighth Biennial Conference of the International Association for the Study of Common Property (IASCP), Bloomington, IN, USA, 31 May-4 June 2000; pp. 1-25.

59. Djihouessi, M.B.; Aina, M.P.; Kpanou, B.-V.; Kpondjo, N. Measuring the Total Economic Value of Traditional Sand Dredging in the Coastal Lagoon Complex of Grand-Nokoué (Benin). J. Environ. Prot. 2017, 8, 1605-1621. [CrossRef]

60. Schwartz, D. Méthodes Statistiques à L'usage des Médecins et des Biologistes; Flammarion: Paris, France, 1963.

61. Oswald, A.J.; Wu, S. Objective Confirmation of Subjective Measures of Human Well-Being: Evidence from the U.S.A. Science 2010, 327, 576-580. [CrossRef] [PubMed]

62. Chambers, R.; Conway, G.R. Sustainable rural livelihoods: Practical concepts for the 21st century. IDS Discuss. Pap. 1992, $296,34$.

63. Young, H.; Jaspars, S.; Brown, R.; Frize, J.; Khogali, H. Food-Security Assessments in Emergencies: A Livelihoods Approach; Humanitarian Practice Network (HPN): London, UK, 2001.

64. Agrawal, A. Common property institutions and sustainable governance of resources. World Dev. 2001, 29, 1649-1672. [CrossRef]

65. Long, J.S.; Freese, J. Regression Models for Categorical Dependent Variables using Stata, 2nd ed.; Stata Press: College Station, TX, USA, 2006; ISBN 1-59718-011-4.

66. Chattterjee, S.; Hadi, A.S.; Price, B. Regression Analysis by Examples, 3rd ed.; Willey: New York, NY, USA, 2000.

67. Schlenker, W.; Lobell, B.D.; Bryan, E.; Ringler, C.; Okoba, B.; Roncoli, C.; Silvestri, S.; Herrero, M.; Nhemachena, C.; Rashid, H.; et al. Determinants of African farmers' strategies for adapting to climate change: Multinomial choice analysis. Environ. Manag. 2010, 114, 83-104.

68. Cinner, J.E.; McClanahan, T.R.; MacNeil, M.A.; Graham, N.A.J.; Daw, T.M.; Mukminin, A.; Feary, D.A.; Rabearisoa, A.L.; Wamukota, A.; Jiddawi, N.; et al. Comanagement of coral reef social-ecological systems. Proc. Natl. Acad. Sci. USA 2012, 109, 5219-5222. [CrossRef]

69. Ostrom, E. Governing the Commons; Alt, J.E., North, D.C., Eds.; Cambridge University Press: Cambridge, UK, 1990.

70. Ostrom, E. The Evolution of Institutions for Collective Action; Alt, J.E., North, D.C., Eds.; Political; Cambridge University Press: Cambridge, UK, 1990.

71. Kosamu, I.B.M. Conditions for sustainability of small-scale fisheries in developing countries. Fish. Res. 2015, 161, 365-373. [CrossRef]

72. Khan, M.A.; Alam, M.F.; Islam, K.J. The impact of co-management on household income and expenditure: An empirical analysis of common property fishery resource management in Bangladesh. Ocean Coast. Manag. 2012, 65, 67-78. [CrossRef]

73. Keyzer, M.A.; Sonneveld, B.G.J.S.; Van Veen, W.C.M. Valuation of natural resources: Efficiency and equity. J. Dev. Pract. 2009, 19, 233-239. [CrossRef]

74. Cledjo, P. La gestion locale de l'environnement dans les cités du lac Nokoué: Région urbaine du littoral du sud Bénin. Ph.D. Thesis, Université d'Abomey-Calavi, Abomey Calavi, Benin, 1999.

75. INSAE. Note sur la Pauvreté au Bénin en 2019; Institut National de la Statistique et de l'Analyse Economique, Ministère du Plan et du Développement: Cotonou, Bénin, 2020.

76. PACOFIDE. Cadre de Gestion Environnementale et Sociale.Projet D'appui à la Compétitivité des Filières et à la Diversification des Exportations; Ministère de L'agriculture, de L'élevage et de la Pêche: Cotonou, Benin, 2018.

77. Hounssounou, C.L. Analyse des Dynamiques Sociales Autour de la Surexploitation des Ressources Halieutiques par la Senne de Plage au Bénin. Ph.D. Thesis, Université d'Abomey-Calavi, Abomey Calavi, Benin, 2014.

78. Hounsounou, L.C.; Akouèhou, G.S.; Mongbo, R.L. Une analyse de la dynamique spatiale de pêche à la senne de plage au Bénin. Bull. Rech. Agron. Bénin 2012, 884, 48-51. 